Article

\title{
Microwave-assisted synthesis of defective tungsten trioxide for photocatalytic bacterial inactivation: Role of the oxygen vacancy
}

\author{
Wenquan Gua a, Wanjun Wang a,*, Guiying Li a, Haojing Xie a, Po Keung Wong b, Taicheng An a \\ a Guangzhou Key Laboratory Environmental Catalysis and Pollution Control, Guangdong Key Laboratory of Environmental Catalysis and Health Risk \\ Control, School of Environmental Science and Engineering, Institute of Environmental Health and Pollution Control, Guangdong University of \\ Technology, Guangzhou 510006, Guangdong, China \\ b School of Life Sciences, The Chinese University of Hong Kong, Shatin, NT, Hong Kong, China
}

\section{A R T I C L E I N F O}

\section{Article history:}

Received 22 December 2019

Accepted 31 January 2020

Published 5 October 2020

\section{Keywords:}

Photocatalysis

$\mathrm{WO}_{3}$

Microwave

Oxygen vacancy

Bacterial inactivation

\begin{abstract}
A B S T R A C T
Surface defect modulation has emerged as a potential strategy for promoting the photocatalytic activity of photocatalysts for various applications, while the impact of the oxygen vacancy on bacterial inactivation is still debated. In this study, oxygen vacancies were introduced to tungsten trioxide nanosheets $\left(\mathrm{WO}_{3-x}\right)$ via a microwave-assisted route. The as-prepared $\mathrm{WO}_{3-x}$ nanosheets exhibited excellent visible-light-driven photocatalytic activity toward E. coli K-12 inactivation, and 6 log orders of the bacterial cells could be completely inactivated within $150 \mathrm{~min}$. The obtained bacterial inactivation rate constant was 15.2 times higher than that of pristine $\mathrm{WO}_{3}$ without oxygen vacancies, suggesting that the surface oxygen vacancy could significantly promote the bacterial inactivation efficiency. The mechanism study indicated that the inactivation of bacterial cells occurs via a direct $\mathrm{h}^{+}$oxidation pathway. In addition, the role of the oxygen vacancy was studied in detail; the oxygen vacancy was found to not only promote interfacial charge separation but also tune the band structure of $\mathrm{WO}_{3}$, thereby leading to increased $\mathrm{h}^{+}$oxidation power. Finally, a possible oxygen vacancy-dominated photocatalytic bacterial inactivation mechanism is proposed. This work is expected to offer new insights into the microwave-assisted synthesis of defective photocatalysts and the use of the oxygen vacancy for promoting photocatalytic antibacterial activities.
\end{abstract}

(C) 2020, Dalian Institute of Chemical Physics, Chinese Academy of Sciences. Published by Elsevier B.V. All rights reserved.

\section{Introduction}

The safety of drinking water has attracted considerable attention. Traditional water disinfection methods including ozonation, chlorination, and UV disinfection have many drawbacks, such as the production of carcinogenic disinfection byproducts (DBPs), bacterial recolonization, and high costs due to energy-intensive processes [1]. Therefore, there is an urgent need to identify a green and cost-effective alternative technology for water disinfection. $\mathrm{TiO}_{2}$-based photocatalysis has been applied successfully for cost-effective bacterial inactivation since 1985, because solar energy, which is inexhaustible, can be used as the energy source [2]. However, the classic photocatalyst, $\mathrm{TiO}_{2}$, can only be excited by UV light, which accounts for merely $5 \%$ of the solar spectrum. To utilize solar energy more effectively, various visible-light-driven (VLD) photocatalysts have been

\footnotetext{
* Corresponding author. Tel/Fax: +86-20-39322298, E-mail: wanjun@gdut.edu.cn

This work was supported by the National Natural Science Foundation of China (21607028, 41425015 and 41573086), the Research Grant Council of Hong Kong SAR Government (GRF14100115), Science and Technology Project of Guangdong Province (2017A050506049), Local Innovative and Research Teams Project of Guangdong Pearl River Talents Program (2017BT01Z032), Innovation Team Project of Guangdong Provincial Department of Education (2017KCXTD012), and Leading Scientific, Technical and Innovation Talents of Guangdong Special Support Program (2016TX03Z094). DOI: S1872-2067(19)63409-1 | http://www.sciencedirect.com/science/journal/18722067 | Chin. J. Catal., Vol. 41, No. 10, October 2020
} 
developed for organic pollutant degradation as well as bacterial inactivation, such as $\mathrm{BiVO}_{4}$ [3] and $\mathrm{g}-\mathrm{C}_{3} \mathrm{~N}_{4}$ [4]. However, the bacterial inactivation efficiency is still far from satisfactory; consequently, commercial applications are not feasible yet. More powerful strategies are highly desired to improve the photocatalytic bacterial inactivation efficiency.

Surface defects engineering has been portrayed as a promising way to promote the photocatalytic activity. Among all the defects studied in semiconductors, oxygen vacancies are one of the most widely distributed in various metal oxides [5]. It has been revealed that oxygen vacancies can simultaneously improve the absorption of photons and the separation of photo-induced charge carriers [6]. In addition, oxygen vacancies on semiconductor surfaces were reported to facilitate the dissociative adsorption of reactant molecules, thereby reducing their activation energy and accelerating the reactions for a variety of applications, including $\mathrm{H}_{2}$ evolution, organic pollutant degradation, and $\mathrm{CO}_{2}$ reduction [7-10]. However, studies on the influence of oxygen vacancies on the photocatalytic bacterial inactivation efficiency are rather limited. Therefore, developing oxygen vacancy deficient photocatalysts and studying their effects on the bacterial inactivation efficiency is attractive.

Among many semiconductors, $\mathrm{WO}_{3}$ is an excellent semiconductor with visible light response, and it has been extensively utilized as a photocatalyst in pollutant degradation [11], water oxidation [12], and gas sensors [13]. Nevertheless, the band gap energy of bulk $\mathrm{WO}_{3}$ is relatively large (about $2.7 \mathrm{eV}$ ), corresponding to a cutoff wavelength of $460 \mathrm{~nm}$; consequently, the solar spectrum in its entirety cannot be utilized effectively [14]. In addition, due to the rapid recombination rate of photo-generated charge carriers and the narrow photon absorption range, pristine $\mathrm{WO}_{3}$ exhibits a low photocatalytic activity [15]. Therefore, a number of strategies have been utilized to modify $\mathrm{WO}_{3}$ and improve its photocatalytic activity, such as morphology control [16], ion doping [17], heterojunctions formation [18], and surface defects engineering [19]. Recent studies have also revealed that strongly localized surface plasmon resonances (LSPR) were detected on defective $\mathrm{WO}_{3-x}$, which performs a similar function to that of plasmonic noble metals (e.g., Au and Ag) [20,21]. Although few studies have investigated the use of $\mathrm{WO}_{3}$-based materials for photocatalytic disinfection [22], the influence of the surface oxygen vacancy on the bacterial inactivation efficiency is still a blank field. Conversely, oxygen vacancy-deficient $\mathrm{WO}_{3-x}$ nanosheets are often synthesized by hydrogen thermal treatment methods, which suffer from high temperature owing to the use of explosive hydrogen gas [23], or by hydrothermal method with long reaction time (> $24 \mathrm{~h}$ ) [24]. Therefore, safe and facile methods are required from the prospect of large-scale application.

In this work, a fast microwave-assisted route was successfully used to fabricate $\mathrm{WO}_{3-x}$. The photocatalytic bacterial inactivation efficiency against $E$. coli was studied under VL irradiation. Considering the as-prepared $\mathrm{WO}_{3-x}$ as an example, the effect of the oxygen vacancy on the bacterial inactivation efficiency was investigated in detail. In addition, the bacterial inactivation mechanism was elucidated in terms of major reactive species and charge separation efficiency. As a proof-of-concept, this work not only provides a simple synthesis method for fabricating photocatalysts with surface oxygen vacancies but also sheds light on the mechanisms for the oxygen vacancy-mediated enhancement of photocatalytic bacterial inactivation efficiency.

\section{Experimental}

\subsection{Synthesis of $\mathrm{WO}_{3-x}$ nanosheets}

All the reagents used were of analytical grade and were used as received; all the aqueous solutions were prepared using deionized water. $\mathrm{WO}_{3-x}$ was prepared by a microwave solvothermal method. Briefly, $1.0 \mathrm{~g}$ of $\mathrm{WCl}_{6}$ (Aladdin Industrial Corporation, 99\%), as the $\mathrm{W}^{6+}$ precursor, was dissolved in 200 $\mathrm{mL}$ of absolute ethanol with stirring for $35 \mathrm{~min}$ to form a transparent yellow solution. Subsequently, the resulting transparent yellow solution was immediately transferred to a Teflon-lined autoclave. After sealing, the autoclave was heated at $150{ }^{\circ} \mathrm{C}$ for $4 \mathrm{~h}$ in a microwave hydrothermal synthesizer (XH-800G, Beijing Xiang Hu, China). The vessel was cooled naturally to room temperature, and the resulting product was collected by centrifugation. After washing with ethanol and distilled water severally, the final $\mathrm{WO}_{3-x}$ product was dried in a vacuum oven at $50{ }^{\circ} \mathrm{C}$ overnight. For comparison, commercial $\mathrm{WO}_{3}$ (Shanghai Macklin Biochemical Co. Ltd., 99.8\%) was used as pristine $\mathrm{WO}_{3}$ without oxygen vacancies.

\subsection{Characterization of materials}

The crystal structures of the as-prepared materials were characterized by powder X-ray diffraction (XRD) ( $\mathrm{Cu} \mathrm{K}_{\alpha}$, D/max-Ultima IV). The morphologies and microstructures were studied by scanning electron microscopy (SEM) (SU8220, Hitachi, Japan) and transmission electron microscopy (TEM) (FE-HRTEM, Talos F200s, FEI Company). UV-Vis absorption spectra were recorded using a Cary 100 spectrophotometer (Agilent, USA). X-ray photoelectron spectroscopy (XPS) was performed on an Escalab 250Xi instrument (Thermo Fisher Scientific). All binding energies were calibrated using a carbon contaminant (C $1 s=284.8 \mathrm{eV}$ ). Electron parameter resonance (EPR) spectroscopy measurements were conducted using a Bruker EMXPluse EPR spectrometer. The photoluminescence (PL) spectra of the samples were obtained using a fluorescence spectrometer (Edinburgh FLS1000) with a Xe lamp as the excitation source. EIS tests were conducted with a three-electrode cell using an electrochemical workstation (CHI 650E, Shanghai Chenhua Instruments, China). Fluorine-doped tin oxide (FTO) glasses were used to prepare the working electrodes. Briefly, 5 mg of $\mathrm{WO}_{3-x}$ was mixed with ethanol $(0.2 \mathrm{~mL})$ by ultrasonication to produce a slurry. Subsequently, the slurry was injected uniformly onto the FTO glass and dried at $60^{\circ} \mathrm{C}$. The effective working area was $1 \mathrm{~cm}^{2}$. A saturated $\mathrm{Ag} / \mathrm{AgCl}$ electrode and a Pt plate were used as the reference electrode and counter electrode, respectively. EIS examinations were conducted across the frequency range from $f_{\max }=100 \mathrm{kHz}$ to $f_{\min }=1 \mathrm{~Hz}$ at $0.5 \mathrm{~V}$ with a perturbation signal of $5 \mathrm{mV}$. 


\subsection{Photocatalytic bacterial inactivation}

E. coli was used as the representative bacterium to test the photocatalytic bacterial inactivation activity, as it is the most common indicator for microbial contamination in drinking water. A $300 \mathrm{~W}$ Xe lamp with a UV cutoff filter $(\lambda<420 \mathrm{~nm})$ was used as the light source, and the light intensity was fixed at $194 \mathrm{~mW} / \mathrm{cm}^{2}$. The final bacterial cell density and catalyst concentration were adjusted to $1 \times 10^{6} \mathrm{cfu} / \mathrm{mL}$ and $500 \mathrm{mg} / \mathrm{L}$, respectively. The detailed experimental procedures regarding bacterial incubation, sampling, and detection of viable cells can be found in our previous report [3]. For comparison, dark control experiments were conducted with only $\mathrm{WO}_{3-x}$ nanosheets, and light control experiments were carried out in the absence of $\mathrm{WO}_{3-x}$ nanosheets under light irradiation. The bacterial inactivation experiments were conducted in triplicates.

\section{Results and discussion}

\subsection{Characterizations of photocatalyst}

The typical XRD patterns of the as-prepared $\mathrm{WO}_{3-x}$ nanosheets are shown in Fig. 1(A). It is observed that the XRD diffraction pattern can be well indexed as monoclinic $\mathrm{W}_{18} \mathrm{O}_{49}$ $\left(\mathrm{WO}_{2.72}\right)$ (JCPDS No. 71-2450, space group: $\left.P 2 \mathrm{~m}\right)$. The major peaks located at $23^{\circ}, 26^{\circ}, 35^{\circ}$, and $47^{\circ}$ can be attributed to (010), (-104), (113), and (020) crystal planes, respectively, which is consistent with previous studies [24,26]. In addition, no other impurities are detected, suggesting that the $\mathrm{WO}_{3-x}$ nanosheet can be successfully synthesized by the microwave solvothermal method at $150{ }^{\circ} \mathrm{C}$ for $4 \mathrm{~h}$. The synthesis condition is much milder than that of the conventional solvothermal method $\left(180{ }^{\circ} \mathrm{C}\right.$ for $24 \mathrm{~h}$ ) [24] because microwave heating has been reported to drastically enhance the crystallization kinetics, up to two orders of magnitude, due to the intense super heating localized to the aqueous solution [25]. The starting material was $\mathrm{WCl}_{6}$, which is also much cheaper than $\mathrm{W}(\mathrm{CO})_{6}$ used in previous reports $[26,27]$. Therefore, the present microwave-assisted method in the study shows promise for potential low-cost and large-scale applications. To evaluate the photostability, the $\mathrm{WO}_{3-x}$ nanosheets, after the photocatalytic disinfection reaction, were also tested. The result showed that the crystal structure of $\mathrm{WO}_{3-x}$ remained unchanged, suggesting
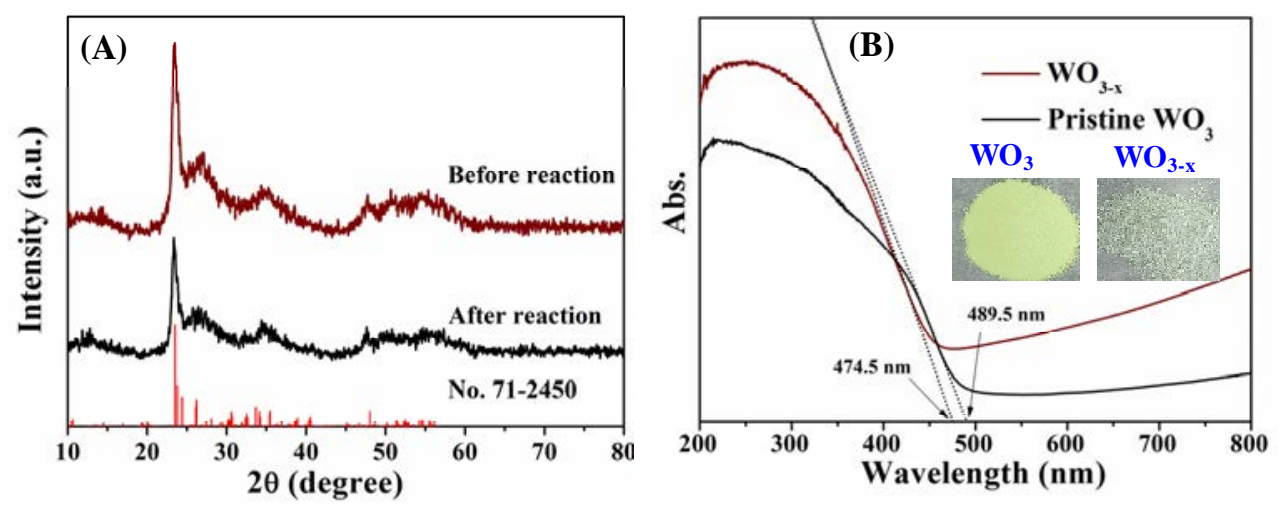

Fig. 1. (A) X-Ray diffraction (XRD) patterns of $\mathrm{WO}_{3-x}$ nanosheets; (B) UV-Vis DRS spectra of the $\mathrm{WO}_{3-x}$ nanosheets and pristine $\mathrm{WO}_{3}$. that the as-prepared $\mathrm{WO}_{3-x}$ nanosheets possess substantial photostability.

The optical absorption was evaluated using the UV-Vis absorption spectra. As shown in Fig. 1(B), the pristine $\mathrm{WO}_{3}$ shows an absorption edge at about $489.5 \mathrm{~nm}$; thus, the band gap energy can be estimated to be $2.53 \mathrm{eV}$. In contrast, the as-prepared $\mathrm{WO}_{3-x}$ nanosheets exhibit an absorption edge at about $474.5 \mathrm{~nm}$, which corresponds to a band gap energy of $2.61 \mathrm{eV}$. A blue shift of the band gap for the $\mathrm{WO}_{3-x}$ nanosheets can be clearly observed, which can be attributed to the quantum confinement effect of the nanomaterials [28-30]. Impressively, it is noted that the $\mathrm{WO}_{3-x}$ nanosheets show a very large absorption tail, which almost covers the entire visible light region (i.e., $500-800 \mathrm{~nm}$ ). This can be attributed to the surface oxygen vacancies formed on the photocatalysts, which lead to a broad and strong SPR absorption in the visible light region, according to the references [31,32]. As shown in the inset of Fig. 1(B), the colors of the $\mathrm{WO}_{3}$ samples change from yellowish-green to grayish-blue, suggesting that the light absorption property was enhanced after the introduction of the oxygen vacancies on the $\mathrm{WO}_{3}$ sample [33].

The morphologies of $\mathrm{WO}_{3-x}$ and pristine $\mathrm{WO}_{3}$ were studied by SEM and TEM. As shown in Fig. 2(A), the pristine $\mathrm{WO}_{3}$ particles exhibit large square morphologies with wide size distributions $(20-100 \mu \mathrm{m})$. Interestingly, the $\mathrm{WO}_{3}$ nanosheet prepared by the microwave solvothermal method exhibits a morphology with a thickness of $<20 \mathrm{~nm}$ and side length of several hundreds of nanometers (Fig. 2(B)). The corresponding EDX spectrum verifies that the sample is constituted by $\mathrm{O}$ and $\mathrm{W}$ elements without other impurities (Fig. 2(C)). The molar ratio of $\mathrm{W}$ to $\mathrm{O}$ in the $\mathrm{WO}_{3-x}$ nanosheets is $1: 1.73$, according to the quantitative analysis of the EDX spectrum, which further suggests that the obtained $\mathrm{WO}_{3}$ is nonstoichiometric with the oxygen vacancy. The TEM image in Fig. 2(D) further confirms the morphology of the nanosheet with width and length of about $150 \mathrm{~nm}$ and 300 $\mathrm{nm}$, respectively. In addition, clear lattice fringes are observed in the HRTEM image (inset of Fig. 2(D)), indicating the high degree of crystallinity of the as-prepared $\mathrm{WO}_{3-x}$. The interplanar distance is determined to be $0.37 \mathrm{~nm}$, which can be assigned to the (100) crystal plane of the cubic phase of $\mathrm{WO}_{3}$. The $\mathrm{N}_{2}$ adsorption/desorption of $\mathrm{WO}_{3-x}$ is determined to be the type-IV isotherm with a hysteresis loop (Fig. S1), which is typical for mesoporous materials. The BET surface areas of $\mathrm{WO}_{3}$ 


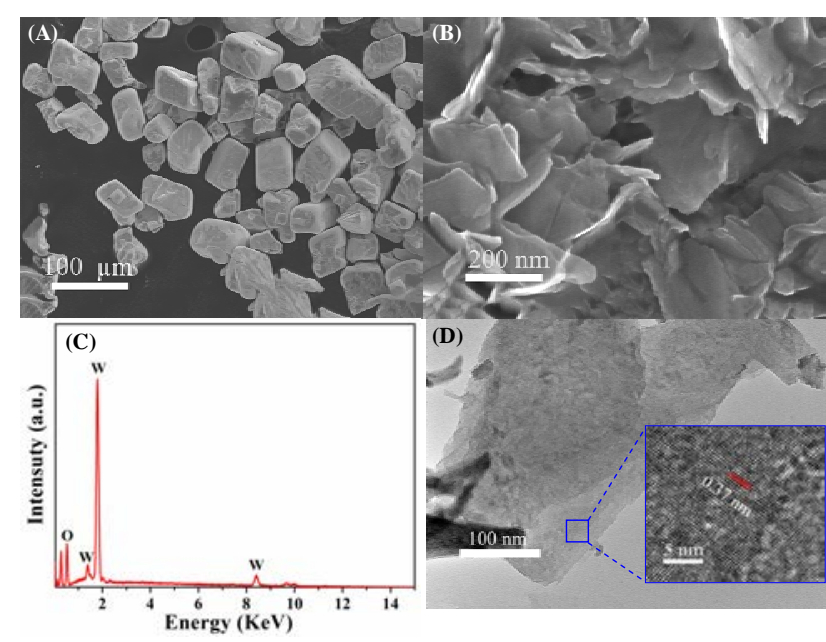

Fig. 2. SEM images of the (A) $\mathrm{WO}_{3-x}$ nanosheets and (B) pristine $\mathrm{WO}_{3}$; (C) EDX spectrum obtained from $\mathrm{WO}_{3-x}$; (D) TEM and HRTEM images of $\mathrm{WO}_{3-x}$.

and $\mathrm{WO}_{3-x}$ were determined to be 7.52 and $30.23 \mathrm{~m}^{2} / \mathrm{g}$, respectively. Noticeably, the $\mathrm{WO}_{3-x}$ nanosheets have much larger specific surface areas than those of the pristine $\mathrm{WO}_{3}$ nanosheets. In addition, the morphology of the $\mathrm{WO}_{3-x}$ nanosheet favors intimate contact with the cell surfaces by providing more active sites.

To clarify the elemental composition and valance states of the $\mathrm{WO}_{3-x}$ nanosheets, the sample was characterized by XPS. As shown in Fig. 3(A), the co-existence of only $\mathrm{W}$ and $\mathrm{O}$ elements is observed in the survey scan of the $\mathrm{WO}_{3-x}$ nanosheet sample, suggesting the high purity of the $\mathrm{WO}_{3-x}$ nanosheets. The quantitative analysis based on the XPS profiles suggests that the atomic ratio of $\mathrm{W}: 0$ is $1: 2.78$, which is different from the above
EDX results (1:1.73). Since EDX is insensitive to the quantitative detection of light elements (e.g., C, 0 , and N) [34,35], the atomic ratio from XPS should be more reliable. The high-resolution XPS profile of the $\mathrm{W} 4 f$ orbit shows two intense peaks corresponding to $\mathrm{W} 4 f_{5 / 2}$ and $\mathrm{W} 4 f_{7 / 2}$ (Fig. 3(B)). The peaks can be further deconvoluted into two Gaussian components with peak binding energies of 38.0 and $35.8 \mathrm{eV}$, which can be well assigned to $\mathrm{W} 4 f_{5 / 2}$ and $\mathrm{W} 4 f_{7 / 2}$ for $\mathrm{W}^{6+}$, respectively [12,36-38]. The lower binding energy components centered at 37.6 and $35.4 \mathrm{eV}$ represent $\mathrm{W}^{5+}[36,38]$. The spin-orbit splitting energy of $W 4 f_{5 / 2}$ and $W 4 f_{7 / 2}$ is determined to be $2.2 \mathrm{eV}$, in agreement with the literature value $[32,40]$. The obtained atomic ratio of $\mathrm{W}^{6+}$ to $\mathrm{W}^{5+}$ is $0.55: 0.45$. In contrast, the peak intensity of $\mathrm{W}^{5+}$ in pristine $\mathrm{WO}_{3}$ decreases dramatically, and the atomic ratio of $\mathrm{W}^{6+}$ to $\mathrm{W}^{5+}$ is $0.83: 0.17$, suggesting that limited oxygen vacancies exist in pristine $\mathrm{WO}_{3}$ (Fig. $3(\mathrm{C})$ ). The existence of $\mathrm{W}^{5+}$ on the surface of the $\mathrm{WO}_{3-x}$ nanosheets confirms that the oxygen vacancies are formed on the photocatalyst surface [32]. Fig. 3(D) shows the high-resolution $01 s$ spectrum of $\mathrm{WO}_{3-x}$, which can be deconvoluted into three Gaussian curves centered at 530.4, 531.1, and $532.2 \mathrm{eV}$. The intense peak at $530.4 \mathrm{eV}$ can be indexed to the lattice oxygen atoms in metal oxides $[36,38,40]$. The second peak located at $531.1 \mathrm{eV}$ is related to the oxygen species adsorbed in the form of $\mathrm{O}-\mathrm{C}$ on the catalyst surface, and the third peak at $532.2 \mathrm{eV}$ can be assigned to the surface-adsorbed $\mathrm{H}_{2} \mathrm{O}$ [39]. In contrast, the peak intensity corresponding to the adsorbed oxygen is very weak for pristine $\mathrm{WO}_{3}$, suggesting the presence of a small number of surface vacancies (Fig. 3(E)). It should be noted that many surface hydroxyl groups are formed on $\mathrm{WO}_{3-x}$, which favors the trapping of photo-generated $\mathrm{e}^{-}-\mathrm{h}^{+}$pairs, thus inhibiting the undesired charge recombination [40].

To confirm, once more, the existence of oxygen vacancies,
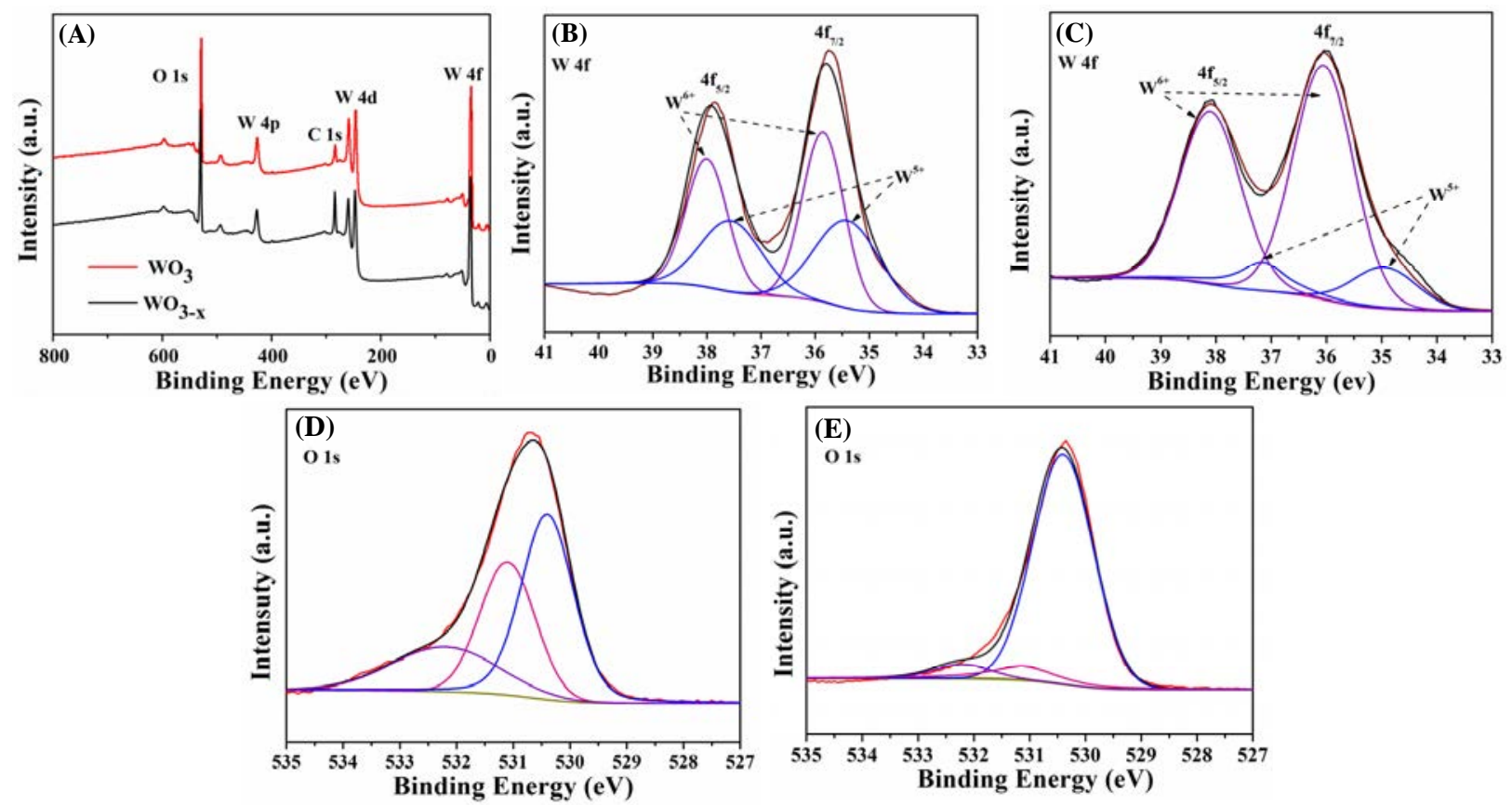

Fig. 3. (A) XPS survey scan of the $\mathrm{WO}_{3-x}$ nanosheets and pristine $\mathrm{WO}_{3}$; High-resolution $\mathrm{W} 4 f \mathrm{XPS}$ profiles of the (B) $\mathrm{WO} \mathrm{O}_{3-x}$ nanosheets and (C) pristine $\mathrm{WO}_{3}$; High-resolution 01 S XPS profiles of the (D) $\mathrm{WO}_{3-x}$ nanosheets and (D) pristine $\mathrm{WO}_{3}$. 


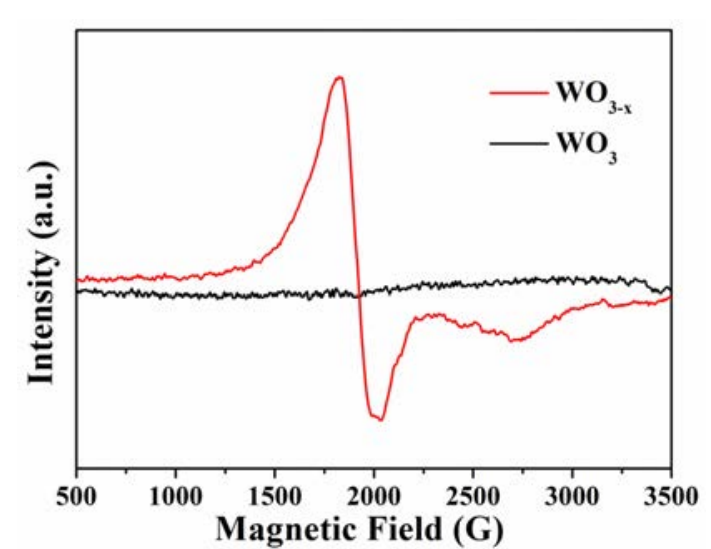

Fig. 4. EPR spectra of the as-prepared $\mathrm{WO}_{3-x}$ nanosheets and pristine $\mathrm{WO}_{3}$.

EPR was used to detect the oxygen vacancies in the $\mathrm{WO}_{3-x}$ nanosheets. The EPR spectroscopy technique has been widely used to study paramagnetic vacancies [41]. As shown in Fig. 4, the $\mathrm{WO}_{3-x}$ displays a sharp signal at a g-value of 2.002 , which is reported to come from the electrons trapped at the oxygen vacancies, according to Ref. [42]. In contrast, no such signal is observed in the pristine $\mathrm{WO}_{3}$. This confirms that oxygen vacancy defects are successfully generated in the $\mathrm{WO}_{3-x}$ by the microwave-assisted method, which is in agreement with the above characterization results. Notably, there is a small peak located around $2700 \mathrm{G}$. This may be due to some unknown W-based defects $[43,44]$, which has also been reported in a previous study [45].

\subsection{Photocatalytic bacterial inactivation efficiency and mechanisms}

The visible-light-driven photocatalytic inactivation was conducted using E. coli $\mathrm{K}-12$ as the representative microorganism due to the wide distribution [46]. As shown in Fig. 5(A), in the light and dark control experiments, the variable cells remained unchanged after $3 \mathrm{~h}$, indicating that the bacterial cells cannot be inactivated under $\mathrm{VL}$ alone and that $\mathrm{WO}_{3-x}$ has no toxic effect on the $E$. coli $\mathrm{K}-12$ cells under dark condition. Interestingly, the as-prepared $\mathrm{WO}_{3-x}$ nanosheets exhibited remarkable photocatalytic inactivation activities under VL irradiation, as in all, 6 log orders of bacterial cells were completely inactivated within $2.5 \mathrm{~h}$ of irradiation. Notably, the bacterial inactivation rate was very low during the first $1 \mathrm{~h}$ of irradiation. This is because, at the initial stage, the bacterial defense system produces high amounts of antioxidant enzymes, including CAT, SOD, and CoA, to overcome the oxidative stress, thereby resulting in reduced inactivation efficiency. Once the defense system is eliminated by more oxidative species with prolonged reaction time, the inactivation efficiency will be dramatically increased. This phenomenon has also been reported in previous studies $[3,47,48]$. In comparison, only about 1.0 log reduction of variable cells was obtained after $3 \mathrm{~h}$ of VL irradiation, with the pristine $\mathrm{WO}_{3}$ as photocatalysts. To quantitatively understand the $E$. coli inactivation rate, the inactivation kinetics were investigated using the Geeraerd model [49]. The inactivation kinetics with $\mathrm{WO}_{3}$ and $\mathrm{WO}_{3-x}$ as the photocatalysts can be fitted into the log-linear-shoulder model (Eq. (1)) using the software, GInaFit:

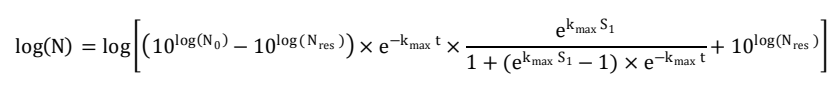

where $N(0)$ is the initial cell density (cfu/mL), $N_{\text {res }}$ is the residual cell density $(\mathrm{cfu} / \mathrm{mL}), k_{\max }$ is the specific inactivation rate constant $\left(\mathrm{h}^{-1}\right)$, and $\mathrm{S}_{\mathrm{l}}$ is the shoulder length $(\mathrm{h})$. As shown in Table S1, $k_{\max }$ values of the bacterial inactivation by the $\mathrm{WO}_{3-x}$ nanosheets and pristine $\mathrm{WO}_{3}$ are calculated to be $\sim 18.87$ and $1.24 \mathrm{~h}^{-1}$, respectively, suggesting that the photocatalytic bacterial inactivation efficiency using the $\mathrm{WO}_{3-x}$ as photocatalyst is about 15.2 times higher than that obtained using pristine $\mathrm{WO}_{3}$ as the photocatalyst. To study the recycling ability of the $\mathrm{WO}_{3-x}$, repeated experiments were conducted using the recycled $\mathrm{WO}_{3-x}$ under the same bacterial inactivation experimental condition. As shown in Fig. 5(B), the photocatalytic bacterial inactivation of $\mathrm{WO}_{3-x}$ was stable at least for 4 cycles. In addition, no distinct crystal structure change was observed in the XRD patterns before and after the reaction (Fig. 1). In the 4th run, the bacterial inactivation efficiency began to drop, probably due to the loss of catalysts during each cycle or the inactivation intermediates adsorbed on the $\mathrm{WO}_{3-x}$.

To understand the photocatalytic mechanism, a scavenging study was performed to identify the major reactive species during the cell inactivation process in the $\mathrm{WO}_{3-x} / \mathrm{VL}$ system.
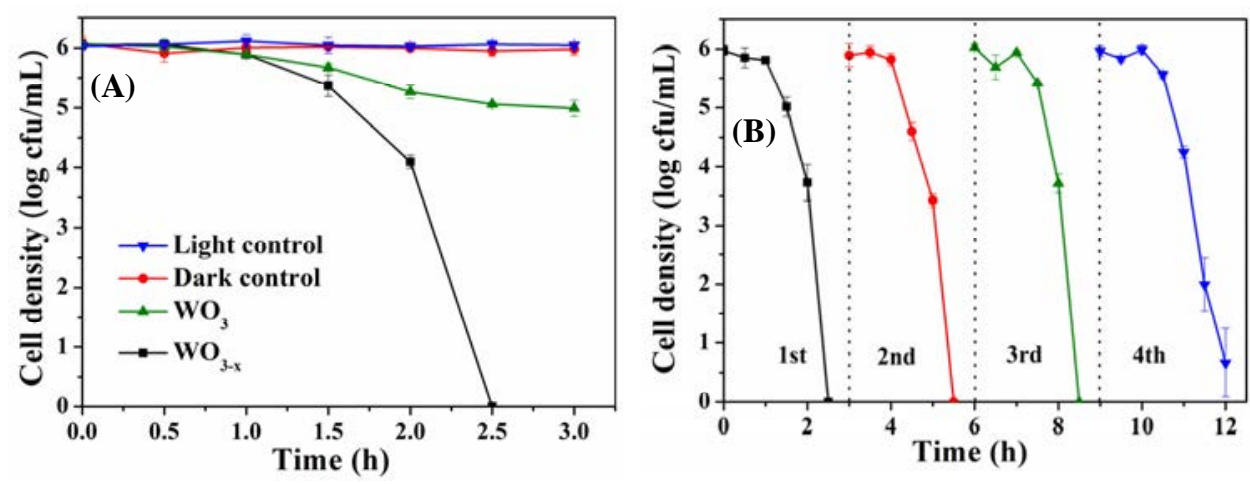

Fig. 5. (A) Photocatalytic inactivation efficiency of $E$. coli $\mathrm{K}-12\left(1 \times 10^{6} \mathrm{cfu} / \mathrm{mL}, 50 \mathrm{~mL}\right)$ under visible light irradiation in the presence of WO $\mathrm{W}_{3-x}$ and pristine $\mathrm{WO}_{3}$; (B) Recycling experiments for the photocatalytic inactivation of $E$. coli $\mathrm{K}-12$ by $\mathrm{WO}_{3-x}$ under visible light irradiation. 
The scavengers used in this work were isopropanol for $\bullet \mathrm{OH}_{\text {bulk }}$ [50], sodium oxalate for $\mathrm{h}^{+}$[51], $\mathrm{Fe}(\mathrm{II})$ for $\mathrm{H}_{2} \mathrm{O}_{2}$ [52], $\mathrm{Cr}(\mathrm{VI})$ for $\mathrm{e}^{-}$[53], and 4-hydroxy-2,2,6,6-tetramethylpiperidin-1-oxyl (TEMPOL) for $\bullet \mathrm{O}_{2}^{-}$[54-56]. As shown in Fig. 6, the addition of isopropanol or $\mathrm{Fe}(\mathrm{II})$ had little influence on the inactivation efficiency, suggesting that $\bullet \mathrm{OH}_{\text {bulk }}$ or $\mathrm{H}_{2} \mathrm{O}_{2}$ is not crucial in the photocatalytic inactivation process. Notably, with the addition of oxalate to trap the photo-induced $\mathrm{h}^{+}$, the bacterial inactivation rate was totally suppressed, which indicates that $\mathrm{h}^{+}$plays the dominant role in the $\mathrm{WO}_{3-x}$ bacterial inactivation process. To study the role of $\bullet^{-}{ }_{2}$, photocatalytic disinfection experiments under an anaerobic condition with $\mathrm{N}_{2}$ bubbling were conducted, and the inactivation efficiency was found to be suppressed. Considering that the removal of $\mathrm{O}_{2}$ could also lead to the insufficient trapping of photo-generated $\mathrm{e}^{-}$, which would significantly promote the undesired recombination of photo-generated $\mathrm{e}^{-}-\mathrm{h}^{+}$pairs, the decrease in the bacterial inactivation efficiency may not only be due to the absence of $\bullet \mathrm{O}_{2}$. Therefore, TEMPOL was further used as a specific scavenger for $\cdot \mathrm{O}_{2}{ }^{-}$, and the results show that the addition of TEMPOL slightly inhibits the inactivation efficiency, suggesting that $\bullet_{2}{ }^{-}$also plays a minor role in the bacterial inactivation process. Moreover, when using $\mathrm{Cr}(\mathrm{VI})$ as the scavenger to quench the photo-generated $\mathrm{e}^{-}$, the inactivation efficiency was enhanced. This is not surprising as the efficient trapping of the photo-generated $\mathrm{e}^{-}$by $\mathrm{Cr}(\mathrm{VI})$ could promote the charge carrier separation and increase the lifetime of $\mathrm{h}^{+}$for oxidation. However, since $\mathrm{h}^{+}$is able to oxidize the $\mathrm{OH}^{-}$adsorbed on the catalyst surface to produce $\bullet \mathrm{OH}\left(\bullet \mathrm{OH}_{\mathrm{ads}}\right)$, the decreased inactivation efficiency when using $\mathrm{h}^{+}$scavenger may be due to the loss of $\bullet \mathrm{OH}_{\text {ads. }}$ Therefore, to further investigate the role of $\bullet \mathrm{OH}_{\text {ads }}$ in the bacterial inactivation process, $\mathrm{F}^{-}$surface modification was utilized to substitute the surface hydroxyl groups; thus, the production of $\bullet \mathrm{OH}_{\text {ads }}$ can be inhibited according to the procedure described in our previous report [3]. It was found that the $\mathrm{F}^{-}$ modification exerted no inhibitory effect on the inactivation efficiency, suggesting that the $\bullet \mathrm{OH}_{\text {ads }}$ is not important and the major reactive species is the photo-generated $h^{+}$(Fig. 6). It was

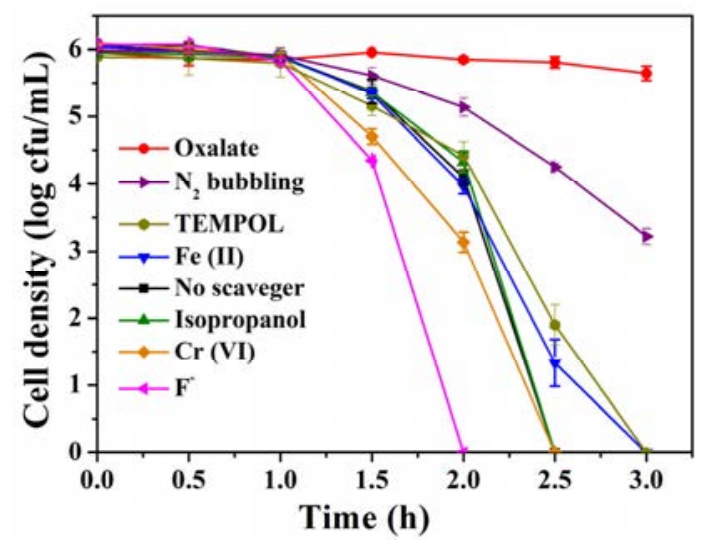

Fig. 6. Photocatalytic inactivation efficiency against E. coli K-12 $\left(1 \times 10^{6}\right.$ $\mathrm{cfu} / \mathrm{mL}, 50 \mathrm{~mL}$ ) with different scavengers (0.05 mmol/L Cr(VI); 0.5 $\mathrm{mmol} / \mathrm{L}$ isopropanol, sodium oxalate, TEMPOL; $0.1 \mathrm{mmol} / \mathrm{L}$ $\mathrm{Fe}(\mathrm{II})$-EDTA; $5 \mathrm{mmol} / \mathrm{L} \mathrm{NaF}$ ) in the presence of $\mathrm{WO}_{3-x}$ nanosheets $(500$ $\mathrm{mg} / \mathrm{L}$ ) under VL irradiation. No bacterial inactivation occurred in the dark and light control samples. also noted that the inactivation efficiency was slightly enhanced after $\mathrm{F}^{-}$modification, which could be due to the promotion of -OHbulk $[3,57]$.

To further understand the intrinsic correlation between the inactivation performance and the oxygen vacancy, the band structure of $\mathrm{WO}_{3-x}$ was studied. The relative VBM positions of $\mathrm{WO}_{3-x}$ were studied in the XPS valence band spectra. As illustrated in Fig. 7(A), $\mathrm{WO}_{3-x}$ nanosheets show a VBM of about 2.62 $\mathrm{eV}$, while pristine $\mathrm{WO}_{3}$ nanosheets show a VBM of about 2.14 $\mathrm{eV}$ with respect to the Fermi level $\left(E_{\mathrm{F}}=0 \mathrm{eV}\right)$. Notably, the position of $E_{\mathrm{F}}$ is referred to as the Au standard with a work function, $\Phi_{\mathrm{Au}}$, of $5.1 \mathrm{eV}$ [58]. Therefore, the $\mathrm{VBM}$ of $\mathrm{WO}_{3-x}$ and $\mathrm{WO}_{3}$ are located at -7.72 and $-7.24 \mathrm{eV}$ vs. VAC, respectively. As mentioned above, $\mathrm{WO}_{3-x}$ and $\mathrm{WO}_{3}$ have band gaps of 2.61 and 2.53 $\mathrm{eV}$, respectively. Therefore the $\mathrm{CBM}$ of pristine $\mathrm{WO}_{3}$ and $\mathrm{WO}_{3-x}$ nanosheets are positioned at -4.71 and $-5.11 \mathrm{eV}$, respectively. A schematic illustration of the band structures of $\mathrm{WO}_{3-x}$ and pristine $\mathrm{WO}_{3}$ is shown in Fig. $7(\mathrm{~B})$. The VBM energy of the $\mathrm{WO}_{3-x}$ nanosheets downshifted by $0.48 \mathrm{eV}$, in comparison with the $\mathrm{WO}_{3}$ case. It is clear that the oxygen vacancy leads to the positive shift of VBM toward higher energy levels, which can increase the oxidation ability of the photo-generated $h^{+}$. Therefore, $\mathrm{WO}_{3-x}$ exhibits significantly higher disinfection activity compared to that of $\mathrm{WO}_{3}$, as the major reactive species in this system is identified to be photo-generated $h^{+}$. Previous studies have reported that an increase in oxygen defects in the metal oxide semiconductor can lead to variations in the optical band gap [59,60]. In addition, Wei et al. in a recent study [61] calcu-
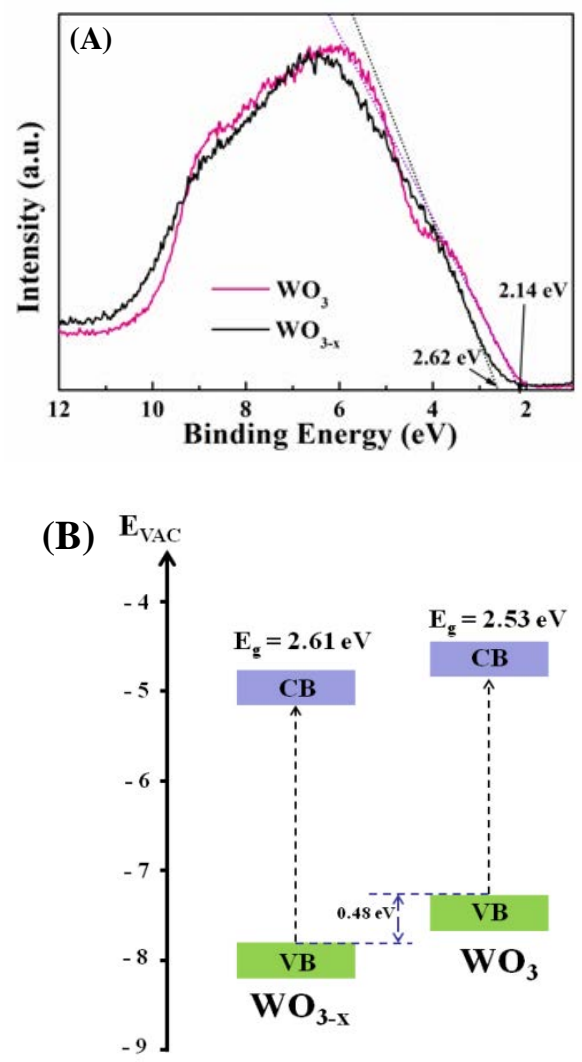

Fig. 7. (A) XPS VB spectra and (B) band alignment of pristine $\mathrm{WO}_{3}$ and $\mathrm{WO}_{3-\mathrm{x}}$. 

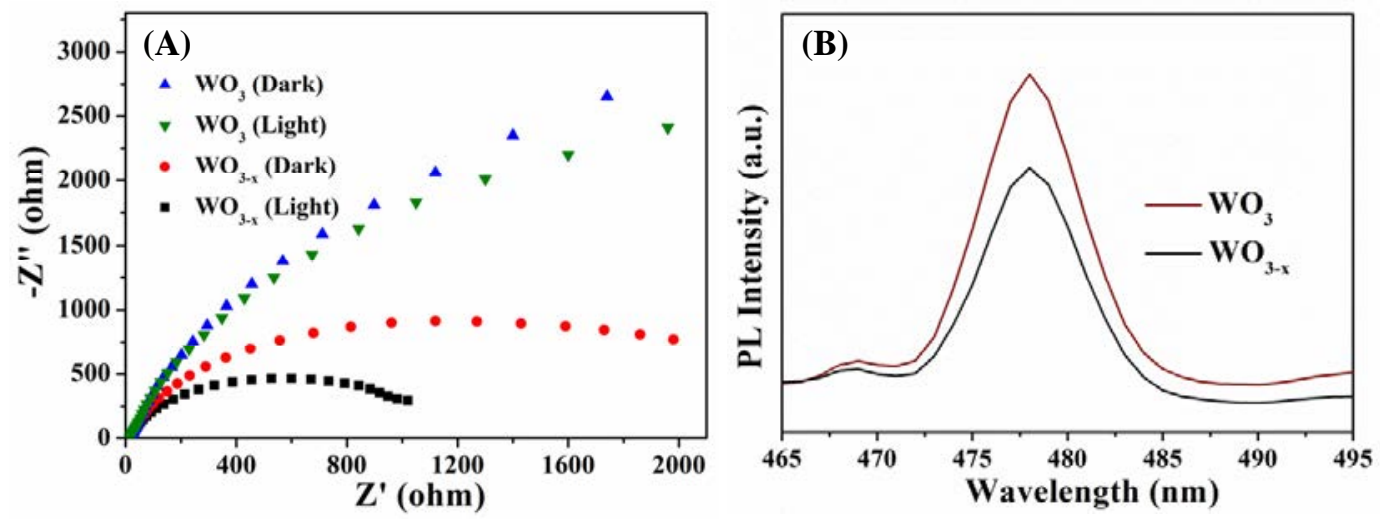

Fig. 8. (A) EIS Nyquist plots for the $\mathrm{WO}_{3}$ and $\mathrm{WO}_{3-x}$ electrodes in the dark and under VL irradiation; (B) Photoluminescence spectra of pristine $\mathrm{WO}_{3}$ and $\mathrm{WO}_{3-x}$ nanosheets at the excitation wavelength of $325 \mathrm{~nm}$.

lated the band structure and found that the oxygen defects in $\mathrm{WO}_{3}$ can form defect band levels below the CBM, which results in the broadening of the band gap and positive shift of VBM toward higher energy levels. This phenomenon of oxygen vacancy-derived positive shift of VBM has also been reported for defective $\mathrm{BiOCl}$ [58]. Moreover, to further confirm the positive shift of the band position, the production of $\bullet \mathrm{O}_{2}{ }^{-}$was monitored using the NBT-trapping method according to the literature [52]. The NBT sodium salt $\left(2.5 \times 10^{-5} \mathrm{~mol} / \mathrm{L}\right.$, absorbance peak at $260 \mathrm{~nm}$ ) will specifically react with $\bullet \mathrm{O}_{2}^{2}$; thus, the decrease in absorbance at $260 \mathrm{~nm}$ is an indicator of the presence of $\bullet_{2}{ }^{-}$ [62]. As shown in Fig. S2, the $\bullet \mathrm{O}_{2}^{-}$production rate by $\mathrm{WO}_{3-x}$ is much lower than that by $\mathrm{WO}_{3}$, which indicates that the reducing power of $\mathrm{CBM} \mathrm{e}^{-}$on $\mathrm{WO}_{3-x}$ is lower than that on $\mathrm{WO}_{3}$, thereby suggesting the positive shift of the overall band position. This will, in turn, increase the oxidation power of $\mathrm{VBM} \mathrm{h}^{+}$, resulting in a relatively high inactivation efficiency. Based on the above discussion, the mechanism of the VLD photocatalytic bacterial inactivation by $\mathrm{WO}_{3-x}$ can be described by the following reactions:

$$
\begin{gathered}
\mathrm{WO}_{3-x}+\mathrm{h} v \rightarrow \mathrm{WO}_{3-x}\left(\mathrm{e}^{-}+\mathrm{h}^{+}\right) \\
\text {Cell }+\mathrm{h}^{+} \rightarrow \text { Damaged cell } \\
\mathrm{OH}^{-} \text {ads }+\mathrm{h}^{+} \rightarrow \bullet \mathrm{OH}_{\text {ads }}
\end{gathered}
$$

EIS measurements were further performed to investigate the interface charge separation efficiency. Fig. 8(A) shows the EIS Nyquist plots of the $\mathrm{WO}_{3-x}$ and $\mathrm{WO}_{3}$ electrodes in dark and under VL irradiation. The charge transfer efficiency on the surface of the electrode can be evaluated by the arc radius. The smaller arc radius suggests a more efficient separation of the photo-generated $\mathrm{e}^{-}-\mathrm{h}^{+}$pairs as well as a higher charge migration rate across the electrolyte/electrode interface [63]. Under the dark condition, the arc radius of $\mathrm{WO}_{3-x}$ electrode is smaller than that of $\mathrm{WO}_{3}$. Under VL irradiation, the arc radii of both samples decrease, suggesting the photo-induced migration of the charge carriers. The arc radius of the $\mathrm{WO}_{3-x}$ electrode is still much smaller than that of $\mathrm{WO}_{3}$. These results indicate that the separation and migration of photo-generated $\mathrm{e}^{-}-\mathrm{h}^{+}$pairs are more rapid on the $\mathrm{WO}_{3-x}$ electrode than on the $\mathrm{WO}_{3}$ electrode. Moreover, the charge separation rate was also determined by the photoluminescence (PL) technique according to Reference
[64]. An intense PL emission peak of $\mathrm{WO}_{3}$ with an excitation wavelength at $325 \mathrm{~nm}$ is observed, as shown in Fig. 8(B). The intensity of this peak is clearly decreased for $\mathrm{WO}_{3-x}$ with sufficient oxygen vacancies. Therefore, these results indicate that besides tuning the band structure, the modulation of the oxygen vacancy is also a good strategy for enabling fast $\mathrm{e}^{-}-\mathrm{h}^{+}$separation, charge carrier migration, and transfer to the targets, thus finally promoting the overall photocatalytic bacterial inactivation rates.

Based on the above results and discussion, the mechanism of the photocatalytic bacterial inactivation by the $\mathrm{WO}_{3-x}$ is proposed. As shown in Fig. 9, when the VL illuminates the catalyst, $\mathrm{e}^{-}-\mathrm{h}^{+}$pairs are generated. The $\mathrm{h}^{+}$species migrates to the catalyst surface and directly reacts with adsorbed bacterial cells. The carboxylate groups on the bacterial surface can be anchored on the surface oxygen defects, thereby significantly increasing the contact between the photocatalysts and bacterial cells, which favors the direct $\mathrm{h}^{+}$transfer reactions. In addition, the abundant oxygen vacancies on the surface of the $\mathrm{WO}_{3-x}$ nanosheets could form impurities within the band structure, thus facilitating the $\mathrm{e}^{-}-\mathrm{h}^{+}$separation. Moreover, the oxygen vacancy leads to the positive shift of the band position, which

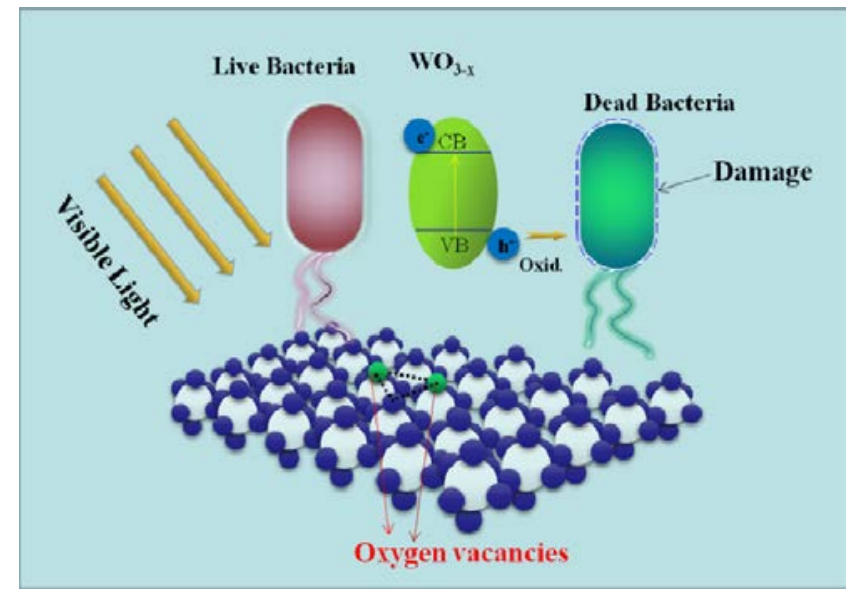

Fig. 9. Schematic of the proposed photocatalytic bacterial inactivation mechanism by $\mathrm{WO}_{3-x}$ under VL irradiation. 
results in a relatively high oxidation potential of the photo-generated $h^{+}$. Eventually, these processes would lead to the promotion of bacterial inactivation efficiency with the modulation of the surface oxygen vacancy.

\section{Conclusions}

In summary, by considering $\mathrm{WO}_{3-x}$ as an example, we demonstrated a new strategy of using oxygen vacancy modulation to promote photocatalytic bacterial inactivation efficiency. A microwave-assisted route was utilized to synthesize $\mathrm{WO}_{3-x}$ nanosheets. The as-prepared $\mathrm{WO}_{3-x}$ exhibited a remarkably enhanced photocatalytic antibacterial activity against $E$. coli in comparison with the pristine $\mathrm{WO}_{3}$ case. The photo-generated $\mathrm{h}^{+}$was identified as the major reactive species, which directly influenced the antibacterial activity rather than produce other indirect oxidative radicals. The introduction of oxygen vacancies did not only lead to the positive shifts of the VB and CB band positions, resulting in the relatively high oxidation power of the photo-generated $\mathrm{h}^{+}$, but also to an increased interfacial charge transfer efficiency on the $\mathrm{WO}_{3-x}$ nanosheets. As a proof-of-concept, this work may have profound implications for developing novel strategies for introducing surface defects in photocatalyst design for water disinfection.

\section{References}

[1] O. K. Dalrymple, E. Stefanakos, M. A. Trotz, D. Y. Goswami, Appl. Catal. B, 2010, 98, 27-38.

[2] W. J. Wang, G. Y. Li, D. H. Xia, T. C. An, H. J. Zhao, P. K. Wong, Environ. Sci.: Nano, 2017, 4, 782-799.

[3] W. J. Wang, Y. Yu, T. C. An, G. Y. Li, H. Y. Yip, J. C. Yu, P. K. Wong, Environ. Sci. Technol., 2012, 46, 4599-4606.

[4] C. Zhang, Y. Li, D. M. Shuai, Y. Shen, W. Xiong, L. Q. Wang, Chemosphere, 2019, 214, 462-479.

[5] X. An, L. Zhang, B. Wen, Z. Gu, L. M. Liu, J. Qu, H. Liu, Nano Energy, 2017, 35, 290-298.
[6] X. B. Chen, L. Liu, P. Y. Yu, S. S. Mao, Science, 2011, 331, 746-750.

[7] X. Y. Pan, M. Q. Yang, X. Z. Fu, N. Zhang, Y. J. Xu, Nanoscale, 2013, 5, 3601-3614.

[8] W. T. Bi, C. M. Ye, C. Xiao, W. Tong, X. D. Zhang, W. Shao, Y. Xie, Small, 2014, 10, 2820-2825.

[9] F. Deng, Q. Zhang, L. Yang, X. Luo, A. Wang, S. Luo, D. D. Dionysiou, Appl. Catal. B, 2018, 238, 61-69.

[10] J. Li, M. Zhang, Z. Guan, Q. Li, C. He, J. Yang, Appl. Catal. B, 2017, 206, 300-307.

[11] Y. Y. Lu, G. Liu, J. Zhang, Z. C. Feng, C. Li, Z. Li, Chin. J. Catal., 2016, $37,349-358$.

[12] G. Liu, J. Han, X. Zhou, L. Huang, F. Zhang, X. Wang, C. Ding, X. Zheng, H. Han, C. Li, J. Catal., 2013, 307, 148-152.

[13] C. Piloto, M. Shafiei, H. Khan, B. Gupta, T. Tesfamichael, N. Motta, Appl. Surf. Sci., 2018, 434, 126-133.

[14] T. Zhang, Z. L. Zhu, H. N. Chen, Y. Bai, S. Xiao, X. L. Zheng, Q. Z. Xue, S. H. Yang, Nanoscale, 2015,7, 2933-2940.

[15] P. Bhavani, D. Praveen Kumar, S. Jeong, E. H. Kim, H. Park, S. Hong, M. Gopannagari, D. A. Reddy, J. K. Song, T. K. Kim, Catal. Sci. Technol., 2018, 8, 1880-1891.

[16] J. Zhou, S. Lin, Y. Chen, A. M. Gaskov, Appl. Surf. Sci., 2017, 403, 274-281.

[17] H. P. Wang, L. Zhang, K. F. Wang, X. Sun, W. Z. Wang, Appl. Catal. B, 2019, 243, 771-779.

[18] K. L. He, J. Xie, X. Y. Luo, J. Q. Wen, S. Ma, X. Li, Y. P. Fang, X. C. Zhang, Chin.J. Catal., 2017, 38, 240-252.

[19] Q. Liu, F. Wang, H. Lin, Y. Xie, N. Tong, J. J. Lin, X. Zhang, Z. Zhang, X. Wang, Catal. Sci. Technol., 2018, 8, 4399-4406.

[20] Z. Zhang, J. Huang, Y. Fang, M. Zhang, K. Liu, B. Dong, Adv. Mater., 2017, 29, 1606688.

[21] Y. Li, Z. Tang, J. Zhang, Z. Zhang, J. Phys. Chem. C, 2016, 120, 9750-9763.

[22] X. Zeng, Z. Wang, G. Wang, T. R. Gengenbach, D. T. McCarthy, A. Deletic, J. Yu, X. Zhang, Appl. Catal. B, 2017, 218, 163-173.

[23] H. F. Cheng, M. Klapproth, A. Sagaltchik, S. Li, A. Thomas, J. Mater. Chem. A, 2018, 6, 2249-2256.

[24] G. C. Xi, S. X. Ouyang, P. Li, J. H. Ye, Q. Ma, N. Su, H. Bai, C. Wang, Angew. Chem. Int. Ed., 2012, 51, 2395-2399.

[25] X. Chen, W. Wang, X. Chen, J. Bi, L. Wu, Z. Li, X. Fu, Mater. Lett.,

\section{Graphical Abstract}

Chin. J. Catal., 2020, 41: 1488-1497 doi: S1872-2067(19)63409-1

\section{Microwave-assisted synthesis of defective tungsten trioxide for photocatalytic bacterial inactivation: Role of the oxygen vacancy}

Wenquan Gu, Wanjun Wang*, Guiying Li, Haojing Xie,

Po Keung Wong, Taicheng An

Guangdong University of Technology;

The Chinese University of Hong Kong

Bacterial inactivation occurs via a direct $\mathrm{h}^{+}$oxidation pathway, in which oxygen vacancy not only promotes the interfacial charge separation but also tunes the band structure to increase the $h^{+}$ oxidation power.

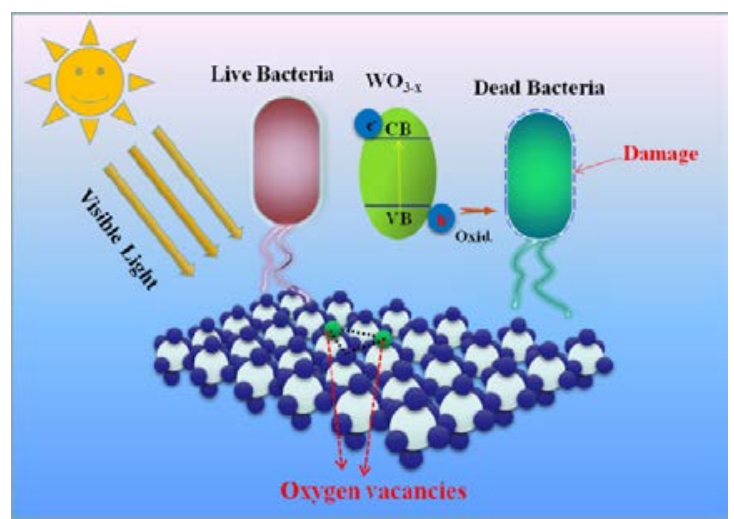


2009, 63, 1023-1026.

[26] Z. Lou, Q. Gu, L. Xu, Y. Liao, C. Xue, Chem. Asian J., 2015, 10, 1291-1294.

[27] Z. Lou, M. Zhu, X. Yang, Y. Zhang, M. H. Whangbo, B. Li, B. Huang, Appl. Catal. B, 2018, 226, 10-15.

[28] M. R. Waller, T. K. Townsend, J. Zhao, E. M. Sabio, R. L. Chamousis, N. D. Browning, F. E. Osterloh, Chem. Mater., 2012, 24, 698-704

[29] N. Xue, R. J. Yu, C. Z. Yuan, X. Xie, Y. F. Jiang, H. Y. Zhou, T. Y. Cheang, A. W. Xu, RSC Adv., 2017, 7, 2351-2357.

[30] T. Edvinsson, R. Soc. Open Sci., 2018, 5, 180387.

[31] E. Grilla, A. Petala, Z. Frontistis, I. K. Konstantinou, D. I. Kondarides, D. Mantzavinos, Appl. Catal. B, 2018, 231, 73-81.

[32] A. K. Nayak, D. Pradhan, J. Phys. Chem. C, 2018, 122, 3183-3193.

[33] Q. Liu, F. Wang, H. Lin, Y. Xie, N. Tong, J. Lin, X. Zhang, Z. Zhang, X. Wang, Catal. Sci. Technol., 2018, 8, 4399-4406.

[34] J. Osán, I. Szalóki, C. U. Ro, R. Van Grieken, Microchim. Acta, 2000, 132, 349-355.

[35] F. C. Miguens, M. L. de Oliveira, R. V. Marins, L. D. de Lacerda, J. Electron Microsc., 2010, 59, 437-446.

[36] N. Zhang, X. Li, Y. Liu, R. Long, M. Li, S. Chen, Z. Qi, C. Wang, L. Song, J. Jiang, Y. Xiong, Small, 2017, 13, 1701354.

[37] J. C. Dupin, D. Gonbeau, P. Vinatier, A. Levasseur, Phys. Chem. Chem. Phys., 2000, 2, 1319-1324.

[38] J. Lu, Y. Wang, F. Liu, L. Zhang, S. Chai, Appl. Surf. Sci., 2017, 393, 180-190.

[39] A. B. Yousaf, M. Imran, S. J. Zaidi, P. Kasak, Sci. Rep., 2017, 7, 6574.

[40] F. Han, H. Li, L. Fu, J. Yang, Z. Liu, Chem. Phys. Lett., 2016, 651, 183-187.

[41] X. Geng, J. You, C. Zhang, J. Alloys Compd., 2016, 687, 286-293.

[42] T. L. Phan, Y. D. Zhang, D. S. Yang, N. X. Nghia, T. D. Thanh, S. C. Yu, Appl. Phys. Lett., 2013, 102, 072408.

[43] D. Zhao, C. C. Chen, C. L. Yu, W. H. Ma, J. C. Zhao, J. Phys. Chem. C, 2009, 113, 13160-13165.

[44] A. Folli, J. Z. Bloh, D. E. MacPhee, J. Electroanal. Chem., 2016, 780, 367-372.

[45] J. Meng, Q. Y. Lin, T. Chen, X. Wei, J. X Li, Z. Zhang, Nanoscale, 2018, 10, 2908-2915.
[46] W. J. Wang, T.W. Ng, W. K. Ho, J. H. Huang, S. J. Liang, T. C. An, G. Y. Li, J. C. Yu, P. K. Wong, Appl. Catal. B, 2013, 129, 482-490.

[47] Y. M. Chen, A. H. Lu, Y. Li, L. S. Zhang, H. Y. Yip, H. J. Zhao, T. C. An, P. K. Wong, Environ. Sci. Technol., 2011, 45, 5689-5695.

[48] T. Q. Wang, M. Z. Sun, H. L. Sun, J. Shang. P. K. Wong, Appl. Surf. Sci., 2019, 464, 43-52.

[49] A. H. Geeraerd, C. H. Herremans, J. F. Van Impe, Int. J. Food Microbiol., 2000, 59, 185-209.

[50] A. Amine-Khodja, A. Boulkamh, C. Richard, Appl. Catal. B, 2005, 59, 147-154.

[51] R. Jin, W. Gao, J. Chen, H. Zeng, F. Zhang, Z. Liu, N. Guan, J. Photochem. Photobiol. A, 2004, 162, 585-590.

[52] D. H. Xia, Z. R. Shen, G. C. Huang, W. J. Wang, J. C. Yu, P. K. Wong, Environ. Sci. Technol., 2015, 49, 6264-6273.

[53] Y. Chen, S. Yang, K. Wang, L. Lou, J. Photochem. Photobiol. A, 2005, $172,47-54$.

[54] D. Lejeune, M. Hasanuzzaman, A. Pitcock, J. Francis, I. Sehgal, Mol. Cancer, 2006, 5, 21-26.

[55] W. J. Wang, L. Z. Zhang, T. C. An, G. Y. Li, H. Y. Yip, P. K. Wong, Appl. Catal. B, 2011, 108-109, 108-116.

[56] W. J. Wang, G. Y. Li, T. C. An, D. K. L. Chan, J. C. Yu, P. K. Wong, Appl. Catal. B, 2018, 238, 126-135.

[57] H. Park, W. Choi, J. Phys. Chem. B, 2004, 108, 4086-4093.

[58] D. D. Cui, L. Wang, K. Xu, L. Ren, L. Wang, Y. X. Yu, Y. Du, W. C. Hao, J. Mater. Chem. A, 2018, 6, 2193-2199.

[59] D. B. Migas, V. L. Shaposhnikov, V. N. Rodin, V. E. Borisenko, J. Appl. Phys., 2010, 108, 093713.

[60] F. Mehmood, R. Pachter, N. R. Murphy, W. E. Johnson, C. V. Ramana, J. Appl. Phys., 2016, 120, 233105.

[61] W. Wei, Y. J. Yao, Q. Zhao, Z. L. Xu, Q. F. Wang, Z. T. Zhang, Y. F. Gao, Nanoscale, 2019, 11, 5535-5547.

[62] D. Zhang, S. Yan, W. Song, Environ. Sci. Technol., 2014, 48, 12645-12653.

[63] R. Wang, W. Zhang, W. Zhu, L. Yan, S. Li, K. Chen, N. Hu, Y. Suo, J. Wang, Chem. Eng. J., 2018, 348, 292-300.

[64] J. Meng, Q. Lin, T. Chen, X. Wei, J. Li, Z. Zhang, Nanoscale, 2018, 10, 2908-2915.

\title{
微波辅助合成缺陷型氧化铇及其光催化杀菌机理：氧空位的作用
}

\author{
古文泉 ${ }^{\mathrm{a}}$, 王万军 ${ }^{\mathrm{a},{ }^{*}}$, 李桂英 ${ }^{\mathrm{a}}$, 谢皓晶 ${ }^{\mathrm{a}}$, 王保强 ${ }^{\mathrm{b}}$, 安太成 ${ }^{\mathrm{a}}$ \\ a广东工业大学环境健康与污染控制研究院, 环境科学与工程学院, 广东省环境催化与健康风险控制重点实验室, \\ 广州市环境催化与污染控制重点实验室, 广东广州510006 \\ b香港中文大学生命科学学院, 香港
}

摘要: 饮用水的微生物污染问题受到越来越多的重视, 函需发展更加安全的饮用水消毒技术. 光催化消毒由于其利用取之 不尽的太阳光作为能源的特点成为近年来最有潜力的 “绿色” 杀菌技术, 然而传统 $\mathrm{TiO}_{2}$ 光催化只能响应紫外光, 并且目前已 报道的可见光响应催化剂的杀菌效率仍然较低, 不能满足应用需求. 表面氧空位修饰是提高光催化剂性能的有效途径, 已 被证明可提高光催化降解、产氢及 $\mathrm{CO}_{2}$ 还原性能, 然而其对于光催化杀菌的增强机制少有研究. $\mathrm{WO}_{3}$ 由于具备可见光催化 性能而受到较多关注, 同时研究表明表面氧空位可提高 $\mathrm{WO}_{3}$ 光吸收性能从而增强活性, 但氧缺陷型 $\mathrm{WO}_{3}$ 的光催化杀菌性能 尚不明确. 另一方面, 氧缺陷 $\mathrm{WO}_{3}$ 多是通过 $\mathrm{H}_{2}$ 热还原制备或长时间水热反应制备, 存在高温易爆、反应时间长等缺点. 本文 以 $\mathrm{WO}_{3}$ 为例, 利用微波辅助溶剂热法合成 $\mathrm{WO}_{3-x}$, 研究其在可见光下的光催化杀菌性能, 探明氧空位对杀菌作用的增强机 制, 提出针对光催化杀菌的缺陷型催化剂制备策略.

研究发现, 以乙醇作为溶剂 $\mathrm{WO}_{3-x}$ 可在 $150^{\circ} \mathrm{C}$ 经 $4 \mathrm{~h}$ 微波加热成功合成, 相对于传统水热合成大幅缩短了制备时间. SEM/TEM表明其为纳米片形貌, UV-Vis DRS结果显示其带隙由 $2.53 \mathrm{eV}$ 增加到 $2.61 \mathrm{eV}$, 主要是由于量子尺寸效应导致带隙 蓝移, 同时发现 $\mathrm{WO}_{3-x}$ 在500-800 nm范围内具有强可见光吸收, 来源于氧空位导致的LSPR吸收. XPS表明 W:O比为 $1: 2.87$, 说明样品含有大量氧空位, 并通过EPR测试进一步证实了氧空位的生成. 光催化杀菌实验表明, $W_{3-x}$ 在可见光 $(\lambda>420$ 
$\mathrm{nm}$ )照射下可在 $150 \mathrm{~min}$ 内实现对 $6 \log$ 大肠杆菌的完全杀灭, 其杀菌反应动力学符合Geeraerd模型, 最大反应速率常数 $k_{\mathrm{max}}$ 为 $18.87 \mathrm{~h}^{-1}$, 是无氧空位 $\mathrm{WO}_{3}$ 的15.2倍, 充分说明表面氧空位修饰是大幅提高 $\mathrm{WO}_{3}$ 光催化杀菌性能的有效途径.

进一步对光催化杀菌机理进行了深入研究, 发现草酸钠(空穴湮灭剂)的加入可完全抑制杀菌反应, 说明细菌灭活主要 是空穴引起的氧化反应, 同时利用表面氟化取代表面羟基实验发现经空穴氧化生成的表面羟基自由基・ $\mathrm{OH}_{\mathrm{ads}}$ 也不是主要的 活性物种, 从而证实 $\mathrm{WO}_{3-x}$ 体系中光催化杀菌主要是通过空穴直接氧化实现. XPS-VB测试表明合成的 $\mathrm{WO}_{3-x}$ 相对于 $\mathrm{WO}_{3}$ 其 价带发生下移, 导致光生空穴的氧化能力提高, 同时电化学阻抗谱(EIS)及稳态苂光光谱(PL)证实 $\mathrm{WO}_{3-x}$ 具有更高的光生电 子-空穴分离率和界面电子传输效率. 这些结果表明氧空位修饰不仅可以通过调控能带结构影响光生空穴氧化能力, 而且 可以提高载流子迁移率从而提高光催化杀菌性能. 综上所述, 本文提供了一种通过微波辅助调控半导体光催化剂表面氧 空位的方法, 并以 $\mathrm{WO}_{3-x}$ 为例阐明了氧空位对光催化杀菌的增强机制, 为今后定向开发缺陷型光催化剂, 实现对病原微生物 的高效控制和杀灭提供了新的研究思路.

关键词: 光催化; 三氧化铇; 微波; 氧空位; 杀菌

收稿日期: 2019-12-22. 接受日期: 2020-01-31. 出版日期: 2020-10-05.

*通讯联系人. 电话: (020)3932 2298, 电子信箱: wanjun@gdut.edu.cn

基金来源：国家自然科学基金(21607028，41425015，41573086); 香港研究资助局基金(GRF14100115); 广东省科技计划 (2017A050506049); 广东省珠江人才计划本土创新科研团队(2017BT01Z032); 广东省教育厅创新团队项目(2017KCXTD012); 广 东特支计划科技创新领军人才(2016TX03Z094).

本文的电子版全文由Elsevier出版社在ScienceDirect上出版(http://www.sciencedirect.com/science/journal/18722067). 